\title{
Bryophyte mass to stem length ratio: A potential metric for eco-physiological response to land use
}

\author{
Jason A. Hubbart ${ }^{1^{*}}$, Elliott Kellner ${ }^{2}$ \\ ${ }^{1}$ Department of Forestry and Department of Soils, Environmental and Atmospheric Sciences, University of Missouri, Columbia, \\ USA; *Corresponding Author: HubbartJ@Missouri.edu \\ ${ }^{2}$ Department of Forestry, University of Missouri, Columbia, USA
}

Received 12 November 2012; revised 12 December 2012; accepted 26 December 2012

\begin{abstract}
Methods of analysis are needed that quantitatively characterize the response of organisms to anthropogenic disturbance. Herein a method is presented that characterizes bryophyte morphological variability in response to timber harvest treatments (clearcut and partial cut). Samples $(n=6196)$ of the semi-aquatic bryophyte Brachythecium frigidum were collected from clearcut, partial cut and full forest stream reaches between August 2003 and October 2005 and analyzed to obtain mass to stem length ratios (M:SL). Results show that relative to a full forest (i.e. full canopy cover condition), average $\mathrm{M}: S L$ ratios were reduced approximately $18 \%$ in the partial cut and $37 \%$ in the clearcut, indicating a decrease in biomass per unit stem length with increasing harvest intensities. Increased light intensities and higher air temperatures resulting from decreased canopy cover in the harvest treatments corresponded to lower M:SL ratios ( 0.31 and 0.24 for the partial cut and clearcut, respectively). Results quantify the morphological response of $B$. frigidum to habitat perturbation, thereby validating the method as a useful assessment of anthropogenic disturbance in post-timber harvest environments. Additional work should be conducted to test the method in other physiographic regions and to isolate bryophyte response to alterations of distinct environmental variables.
\end{abstract}

Keywords: Semi Aquatic Bryophytes; Timber Harvest; Microclimate; Morphological Growth Response

\section{INTRODUCTION}

Multiple authors have identified the need for studies that investigate bryophyte response to post-timber har- vest environments [1-6]. Bryophytes are widely distributed among terrestrial and aquatic environments $[7,8]$ and serve a number of important roles in forested ecosystems by contributing greatly to net primary productivity, nutrient retention, and by providing habitat and a food base for invertebrates [1,3,9]. Binkley and Graham [10] found that bryophytes made up an average of $5 \%$ net primary productivity, $20 \%$ of the understory biomass, and $95 \%$ of the understory photosynthetic tissue in an old-growth Douglas-fir forest of the pacific northwest, USA. Conceivably, semi-aquatic bryophytes may provide the most appropriate indices for anthropogenic change in many ecosystems since they are located at the terrestrial-aquatic interface, and are therefore influenced by changes occurring in both terrestrial and aquatic ecosystems. Timber harvest effects that may prove detrimental to bryophyte health include increased erosion and sediment, altered stream flow regimes, microclimate (including light availability and air and stream temperature) and nutrient regimes [11-21]. Given bryophyte sensitivity to disturbance, forest management including clearcutting or thinning (i.e. partial cutting) may result in nearly immediate changes to bryophyte health.

Bryophytes are known to have a narrow range of tolerance for many microclimatic conditions [8]. For example, low light intensities, low temperatures, and high relative humidity typical of closed canopy forests are assumed to be optimal for bryophytes $[3,22]$. Altered microclimate in post-harvest forests was shown to have detrimental effects on mosses in Acadian-mixed wood [2], boreal [16,23-25], mixed-conifer [3,19], and hemlock-northern hardwood forests [26]. For example, Nelson and Halpern [3] reported a 90\% decline in bryophyte species richness within one year of harvest treatments. Likewise, Shields et al. [26] found an approximately $44 \%$ reduction in bryophyte cover in forest openings compared to undisturbed full forest plots.

A thorough review of recent primary literature concerning the effect of climatic alterations and/or timber harvest impacts on bryophytes suggested that the major- 
ity of studies have utilized community characteristics such as percentage cover, abundance, and various parameters of species richness and composition as measures of bryophyte response [4,6,18-21,24,25,27-33]. Of the studies that have addressed physiological and morphological responses of bryophyte species to altered climate conditions, many have focused on increased temperatures and radiation levels in Artic and sub-Artic ecosystems [34-36], or the response of bryophytes to increased levels of nutrients such as Nitrogen and Phosphorus $[37,38]$. Few studies have focused on physiological and morphological metrics of bryophyte growth response to timber harvest. Notable exceptions include Sollows et al. [22], who found that a species of liverwort (Bazzania trilobata) showed signs of severe desiccation stress, by means of decreased photosynthetic activity and reduced green pigmentation due to changes in microclimate (i.e. increased temperature, increased light intensity, and decreased relative humidity) that followed clearcutting. When closed canopy conditions were simulated in the laboratory, liverworts were capable of resuming photosynthesis and growth, but at rates considerably lower than those observed prior to canopy removal. Dynesius et al. [16] experimentally analyzed the effect of canopy sheltering on bryophyte transplants. Treatment included placement of transplants in positions of contrasting exposure and covering $50 \%$ of sample individuals with spruce branches. Response was evaluated by estimating proportion of living shoots and measuring radial transplant growth. Results showed a statistically significant ( $p$ $<0.0001$ ) negative relationship between light intensity and bryophyte vitality. The results of these two studies indicate that clearcutting may affect bryophyte growth morphology, reduce recovery abilities, and significantly alter bryophyte density following harvest. Understanding how the effects of timber harvest influence bryophyte physiology and morphology will help scientists and land managers better understand how management practices influence riparian biota and water quality in complex forested ecosystems.

The overall objectives of this study were to 1) quantify the physiological/morphological response of a semiaquatic bryophyte (Brachythecium frigidum) to anthropogenic disturbance by means of a new method, specifically the comparison of mass to stem length ratios (M:SL), and 2) characterize the potential for the method to predict aquatic ecosystem alteration in a post-timber harvest riparian ecosystem.

\section{METHODS}

\subsection{Study Site}

The study took place from August 2003 through October 2005 in the Mica Creek Experimental Watershed
(MCEW) located in Shoshone County, northern Idaho, approximately $25 \mathrm{~km}$ southeast of St. Maries, Idaho $\left(47.17^{\circ} \mathrm{N}\right.$ latitude, and $116.25^{\circ} \mathrm{W}$ longitude) (Figures 1 and 2). The Mica Creek Experimental Watershed is a paired and nested catchment study basin that is privately owned and operated by Potlatch Corporation. Both continental and maritime weather patterns influence the watershed. The continental/maritime climate region, which includes northern Idaho, is a unique transitional climate influenced by both maritime and continental weather patterns $[14,39]$. Continental climates are characterized by large seasonal variations in air temperature and strong influences by relatively dry polar air masses, while maritime climates are generally wetter and influenced by the prevailing westerly winds with cool summers and mild winters. Given the distinct climate regime of the region, and the economic importance of the local timber industry, studies are warranted that address impacts of anthropogenic environmental change subsequent to timber harvest. The experimental watershed encompasses the Mica Creek and the West Fork of Mica Creek (2700 hectares) catchments, which are tributaries to the St. Joe River. The watershed varies in elevation from 1000 to 1585 meters at the headwaters, and receives approximately $1400 \mathrm{~mm}$ annual precipitation. The average annual temperature is approximately $4.5^{\circ} \mathrm{C}$. The majority of precipitation falls from November to May, with at least $70 \%$ of all precipitation falling as snow [14].

Vegetation of the MCEW consists of 75- to 85-yearold naturally regenerated conifer stands, while remnant old-growth (pre-harvest) red cedar (Thuja plicata) remains along the upper tributaries of West Fork Mica Creek. Dominant canopy vegetation within the watershed includes red cedar (Thuja plicata), western larch (Larix occidentalis), grand fir (Abies grandis), western white pine (Pinus monticola), western hemlock (Tsuga heterophylla) and Engelmann spruce (Picea engelmannii).

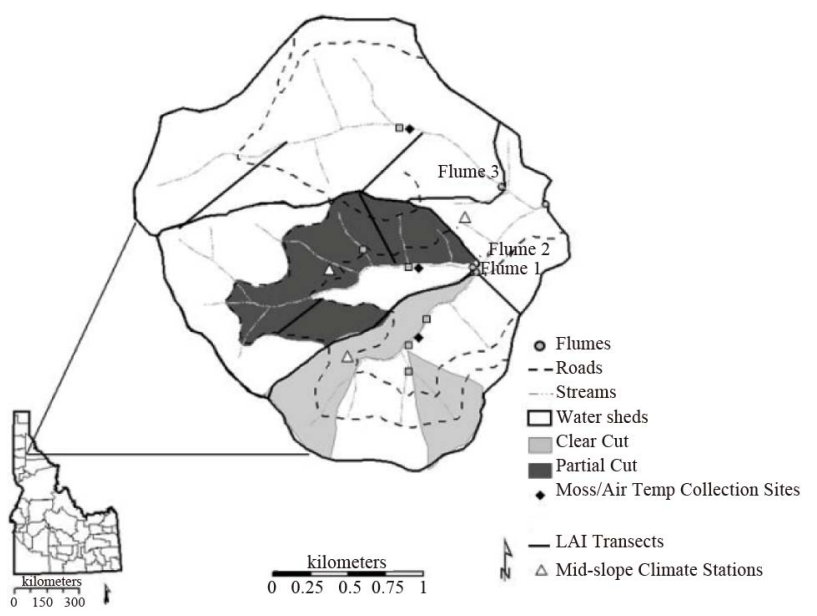

Figure 1. The Mica Creek Experimental Watershed (MCEW) located in the panhandle of northern Idaho, USA. 


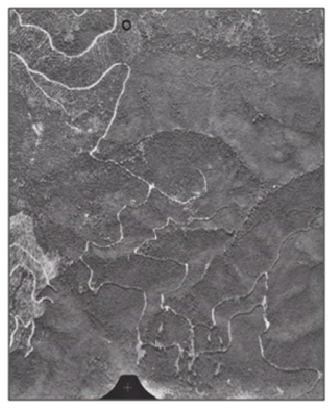

Pre-treatment (2000)

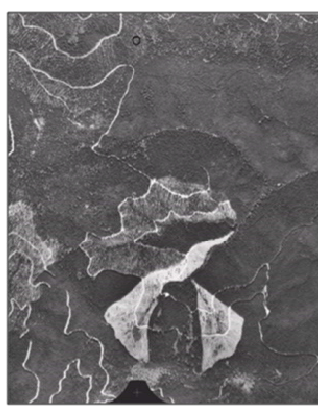

Post-treatment (2002)
Figure 2. Pre- and post-treatment aerial photos of the Mica Creek Experimental Watershed, northern Idaho, USA.

Understory vegetation is largely comprised of grasses, forbs, and shrubs. Stream riparian zones are dominated by alder (Alnus spp.) and dogwood (Cornus spp.) and many stream reaches are well populated with bracken fern (Pteridium acquilinum) undergrowth [14].

\subsection{Forest Harvest}

Timber harvest took place in the late summer and fall of 2001. In the clearcut, whole canopy harvest took place in $50 \%$ of the treatment area, and in the partial cut, $50 \%$ of the canopy was harvested in $50 \%$ of the treatment area. The clearcut was broadcast burned and replanted in May $2003[15,17]$.

Timber harvest followed all Idaho Forest Practices Act regulations for Stream Protection Zone (SPZ) requirements at that time for the protection of in-stream and riparian biota and human beneficial uses. The state of Idaho has set SPZ requirements according to two stream classifications: class I and class II streams. Class I streams are fish bearing and are used for domestic water supply. The SPZ for class I streams must be at least 75 feet $(22.9 \mathrm{~m})$ wide on either side of the high water mark. Harvesting is still permitted in this zone, but $75 \%$ of the original shade must be retained. There are also target leave tree requirements per 1000 linear feet, depending on stream width. Class II streams are non-fish bearing, first order streams. In Idaho, equipment is excluded from a 30 foot $(9.1 \mathrm{~m}) \mathrm{SPZ}$ on either side of the high water mark. There are no shade requirements or leave tree requirements for SPZ's, but skidding logs in or through class II streams is not permitted [40].

\subsection{Canopy Cover}

Canopy cover was estimated using the ceptometer method, which estimates leaf area index (LAI) as per the methods of White et al. [41] and Keane et al. [42]. Using an AccuPAR ceptometer (Decagon Devices, Inc., Pullman, WA), radiometric readings were collected to estimate unimpeded incoming photosynthetically active ra- diation (PAR) in the open and also along two $300 \mathrm{~m}$ transects in the partial cut harvest treatment and full forest (Figures 1 and 2). The sky was clear of clouds during the data collection for this work. Radiometric measurements were collected in the four cardinal directions every $20 \mathrm{~m}$ and then averaged to account for zenith angle, and foliar interception variability. LAI was computed using Eq.1.

$$
L A I=\frac{-\ln \left(Q_{i} / Q_{o}\right)}{k}
$$

where $Q_{i}$ is the amount of radiation at the base of the canopy, $Q_{\mathrm{o}}$ is the amount of incoming radiation above the canopy, and $k$ is a radiation extinction constant (normally assumed, $k=0.5)[43,44]$. Limitations of the ceptometer method can include synchronizing changing light conditions between below and above canopy readings, and adjusting for solar zenith angle [42].

\subsection{Air Temperature}

Climate data were collected from stations installed at mid-slope positions within each treatment type (Table 1) to capture most representative climate variables in each treatment and avoid treatment induced edge effects. Air temperature was monitored with combination temperature/humidity probes in Gill radiation shields (Vaisala, HMP45C, Campbell Scientific, Inc., Logan, UT) in the valley bottom riparian zone in the nested catchment (Figure 1). Air temperature data were simultaneously collected at each riparian sampling site at hourly intervals $3 \mathrm{~m}$ above the water surface with a Thermochron iButton temperature data logger [45]. The device collects time series temperature data within a temperature range of $-20^{\circ} \mathrm{C}$ to $+85^{\circ} \mathrm{C}$ at $0.5^{\circ} \mathrm{C}$ resolution, with a manufacturer stated accuracy of $\pm 1^{\circ} \mathrm{C}$. Hubbart et al. [45] showed that with a sample size of 61 iButton temperature data loggers, the accuracy of the sensors was well within manufacturer stated specifications of $\pm 1.0^{\circ} \mathrm{C}$ with a collective temperature variance of $\pm 0.21^{\circ} \mathrm{C}$. The radiation shield utilized for this work was comprised of a 6- and 8oz white funnel assemblage with a $1-\mathrm{cm}$ space created between the outermost and innermost perforated assemblage allowing passive airflow to the sensor, and thus accurate ambient temperatures as per Hubbart [46]. Stream temperature was not measured at sampling sites. In a peripheral study in the MCEW, Gravelle and Link [13] found that the best management practices (BMP's) employed in the harvest treatments, explained above, effectively mitigated the impact of canopy removal on stream temperature.

\subsection{Semi-Aquatic Bryophyte}

The species of semi-aquatic moss studied in this work was Brachythecium frigidum (C. Muell.) Besch. Brachy- 
Table 1. Local topographic characteristics for mid-slope climate stations located within the Mica Creek Experimental Watershed, northern Idaho, USA.

\begin{tabular}{ccccc}
\hline Treatment & $\begin{array}{c}\text { Elevation } \\
(\mathbf{m})\end{array}$ & Slope (\%) & Aspect (deg) & $\begin{array}{c}\text { Aspect } \\
\text { Categorized }\end{array}$ \\
\hline Clearcut & 1365 & 44 & 46 & NE \\
Patial Cut & 1340 & 20 & 117 & ESE \\
Full Forest & 1299 & 25 & 82 & E \\
\hline
\end{tabular}

thecium frigidum is one of thirty species in this genus that occur in North America. It is found in mesic ecosystems from Alaska to California, Nevada, Utah, Montana, and Wyoming. A study by Jonsson [47] in the western Cascades of Oregon, found B. frigidum to occur along a wide elevation gradient $(420-1250 \mathrm{~m})$ on moist rocky substrates. It was most abundant at higher elevations, but was also common in lower elevation floodplain areas [48-50]. The abundance of this species of bryophyte makes it ideal for this type of study since results are transferable to other regions where $B$. frigidum is also likely to occur.

Bracythecium frigidum samples were collected in three, second order streams of the West Fork of Mica Creek from August 2003 to October 2005, on a quarterly basis ( $\sim 3$ month intervals). Each tributary was influenced by a different harvest condition: clearcut, thinned (partial cut), or fully forested control (Figures 1 and 2). Complete specimens were collected within the riparian zone at the terrestrial-aquatic interface (i.e. water surface) to measure changes occurring where anthropogenic effects are strongest. Sample collection was randomized, with no preference for size and presumably age $(\mathrm{n}=6196)$. Moss samples were promptly placed in properly labeled brown paper bags as per methods described by Jönsson [51], and were allowed to air dry in the bags and stored in the same manner for later analyses. Samples were reconstituted in the lab in tap water for 24 hours in order to rinse out soil and woody debris without damaging the specimen as per methods described by Vargha et al. [52]. Moss samples were then blotted dry with a paper towel to remove any dripping water from samples before being weighed in order to standardize moisture content between samples. After weighing, each sample was dissected into individual stems and spread out on plastic transparency sheets for computer scanning. ImageJ $1.34 \mathrm{~s}$ software (National Institutes of Health ${ }^{\circledR}$ ) was used to trace the scanned images to measure total stem length of each sample. Subsequent to scanning, each sample was weighed again to account for any additional debris that was removed during the dissection process. Post-dissection sample weights were then compared to initial sample weights via regression analysis which indicated that before and after dissection, weights were statistically identical $(\mathrm{p}<0.01)$. On this basis, only pre-dissection weights were included in further analyses. Data were used to create a mass to stem length ratio (M:SL) for each sample, which provided a standardized measure of biomass per unit stem growth for unequally sized samples. Further, the M:SL ratio served as a measure of bryophyte morphological response, which mirrored the bryophyte physiological response to changing land use and environmental variables. One-way ANOVA was utilized to compare means between sites $(\mathrm{p}<0.05)[53$, 54]. Statistical analyses were conducted and graphs were generated utilizing Origin software (Origin Lab Corpora$\left.\operatorname{tion}^{\circledR} 2010\right)$.

\section{RESULTS AND DISCUSSION}

\subsection{Climate during Study}

Meteorological data collected at mid-slope climate stations within each treatment from 1 Nov. 2003 to 14 Oct. 2005, showed many differences between the clearcut, partial cut, and full forest treatments (Table 2, Figure 3). Average mid-slope ambient air temperatures were $6.60^{\circ} \mathrm{C}$, $6.09^{\circ} \mathrm{C}$, and $6.12^{\circ} \mathrm{C}$ in clearcut, partial cut and full forest, respectively. Average ambient air temperatures in the riparian zone (Ta Riparian) were $4.94^{\circ} \mathrm{C}, 4.43^{\circ} \mathrm{C}$ and $4.36^{\circ} \mathrm{C}$ in the clearcut, partial cut and full forest, respectively.

These results show that average air temperatures in the riparian zones were $1.66^{\circ} \mathrm{C}, 1.66^{\circ} \mathrm{C}$, and $1.76^{\circ} \mathrm{C}$ less than air temperatures at mid-slope climate stations in the clearcut, partial cut, and full forest, respectively. In addition, air temperatures measured in the riparian zone displayed a narrower range of variation than air temperatures measured at the mid-slope climate stations (Figure 4). In the riparian zone, average air temperatures ranged from

Table 2. Air temperature (Ta) descriptive statistics from 1 Nov. 2003 to 4 Oct. 2005, at mid-slope and riparian climate stations in clearcut, partial cut, and full forest within the Mica Creek Experimental Watershed, northern Idaho, USA. Min = Minimum, $\mathrm{Max}=$ Maximum, $\mathrm{SD}=$ Standard Deviation.

\begin{tabular}{ccccc}
\hline \multicolumn{5}{c}{ Air Temperature: Mid-Slope $\left({ }^{\circ} \mathbf{C}\right)$} \\
Clearcut & -7.21 & 6.60 & 21.30 & \pm 7.48 \\
Partial Cut & -7.27 & 6.09 & 20.13 & \pm 7.21 \\
Control & -7.12 & 6.12 & 20.14 & \pm 7.19 \\
\hline \multirow{5}{*}{ Air Temperature Riparian $\left({ }^{\circ} \mathbf{C}\right)$} & \\
\hline Clearcut & -4.28 & 4.94 & 16.56 & \pm 6.40 \\
Partial Cut & -4.55 & 4.43 & 16.08 & \pm 6.46 \\
Control & -5.03 & 4.36 & 16.36 & \pm 6.55 \\
\hline
\end{tabular}




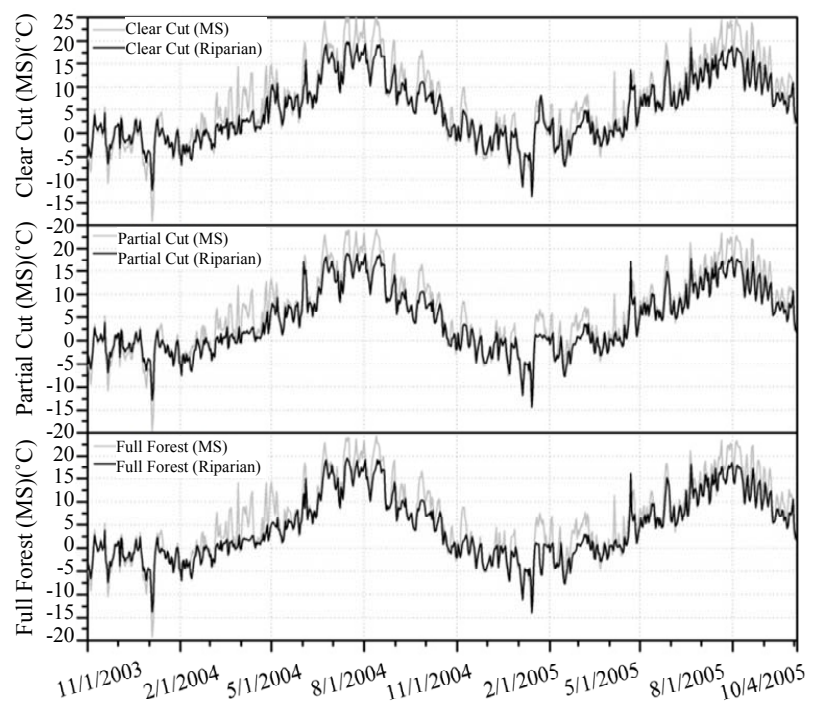

Figure 3. Average mid-slope and riparian air temperatures in clearcut, partial cut, and full forest catchments from 1 Nov. 2003 to 4 Oct. 2005, within the Mica Creek Experimental Watershed in northern Idaho, USA.

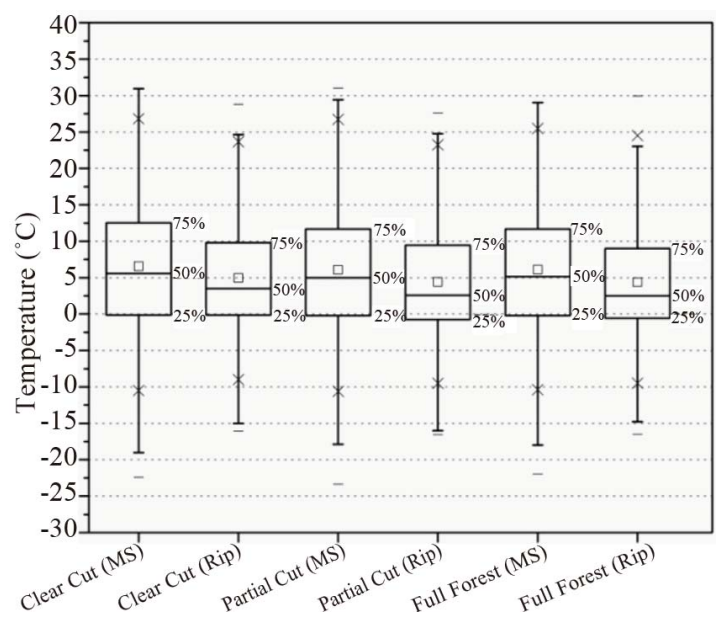

Figure 4. Average air temperature (Ta) box and whisker plots from 1 Nov. 2003 to 4 Oct. 2005, at mid-slope (MS) and riparian (Rip) climate stations in clearcut, partial cut, and full forest within the Mica Creek Experimental Watershed, northern Idaho, USA.

$-4.28^{\circ} \mathrm{C}$ to $16.56^{\circ} \mathrm{C}$ in the clearcut, $-4.55^{\circ} \mathrm{C}$ to $16.08^{\circ} \mathrm{C}$ in the partial cut, and $-5.03^{\circ} \mathrm{C}$ to $16.36^{\circ} \mathrm{C}$ in the full forest, compared to average air temperatures at the midslope climate stations, which ranged from $-7.21^{\circ} \mathrm{C}$ to $21.30^{\circ} \mathrm{C}$ in the clearcut, $-7.27^{\circ} \mathrm{C}$ to $20.13^{\circ} \mathrm{C}$ in the partial cut, and $-7.12^{\circ} \mathrm{C}$ to $20.14^{\circ} \mathrm{C}$ in the full forest.

Air temperature data collected from both the riparian zones and the mid-slope climate stations (Figure 1) showed only slight differences in average air temperature $\left(<1^{\circ} \mathrm{C}\right)$ between the clearcut, partial cut, and full forest treatments (Table 2, Figure 3). However, average air temperatures in the riparian zone were $\sim 25 \%, \sim 27 \%$, and $\sim 29 \%$ lower than average temperatures measured at the climate stations in the clearcut, partial cut and full forest, respectively. The clearcut treatment corresponded with the highest observed air temperatures in both the riparian zone and the treatment plot (Table 2). These results suggest that forest harvest practice had a warming effect on air temperature, even in the adjacent riparian areas. The range of air temperatures observed in the riparian zone was also narrower in comparison to air temperatures observed at the climate stations. In the riparian zone, the range of average air temperatures were $\sim 27 \%, \sim 25 \%$, and $\sim 22 \%$ smaller than the range of air temperatures measured at mid-slope climate stations in the clearcut partial cut, and full forest, respectively (Figure 4).

In addition to shading, lower temperatures in the riparian zones may be partially due to cold air drainage and nocturnal temperature inversion processes that are known to occur in the MCEW [55]. Air temperature differences between the climate stations and the riparian zones also indicated that riparian zones may have a buffering effect against both increases in air temperature and fluctuations in air temperature occurring in adjacent harvest treatments. These results further demonstrate the need to maintain adequate riparian buffer zones in harvested environments to reduce the negative effects of altered temperature regimes on bryophytes and stream ecosystems in general.

\subsection{Bryophyte Morphometrics}

Bryophyte mass to stem length (M:SL) ratios varied broadly between the three harvest treatments (clearcut, partial cut, full forest) following timber harvest (Tables 3 and 4, Figure 5). Dashes in Table 3 indicate no data due to collection complications or sample unsuitability. The mean M:SL ratio was 0.38 in the full forest, 0.31 in the partial cut, and 0.24 in the clearcut. While not statistically significant ( $\mathrm{p}>0.05)$, these results show an $18.4 \%$ reduction of M:SL in the partial cut and 36.8\% reduction of $\mathrm{M}: \mathrm{SL}$ in the clearcut, relative to the full forest control.

Canopy cover was most dense in the full forest, with a mean leaf area index (LAI) of 8.24 (Table 4, Figure 5). The mean LAI in the partial cut was 2.79 (clearcut LAI = 0.0 ). Reduced canopy cover (i.e. lower LAI) in harvested treatments resulted in higher levels of radiation reaching bryophytes in the stream channel. The relatively dense canopy in the full forest corresponded to the highest M:SL ratio of all three treatments $(0.38)$. With less canopy cover in the partial cut, the mean M:SL ratio decreased to 0.31 ; and under little to no canopy cover in the clearcut $(\mathrm{LAI}=0.0)$, the mean M:SL ratio further decreased to 0.24 . These results suggest a positive relationship between the LAI of the forest canopy and the M:SL ratio of $B$. frigidum. Regression analysis between average $\mathrm{M}: \mathrm{SL}$ and LAI $(\mathrm{n}=6)$ resulted in a high coefficient 
Table 3. Mass to stem length ratios by date and treatment in the clearcut, partial cut, and full forest of the Mica Creek Experimental Watershed, northern Idaho, USA.

\begin{tabular}{ccccccc}
\hline \multicolumn{5}{c}{ M:SL by Treatment and Collection Date } \\
\hline \multicolumn{2}{c}{ Clearcut } & \multicolumn{2}{c}{ Partial Cut } & \multicolumn{2}{c}{ Control } \\
\hline Date & M:SL & n & M:SL & n & M:SL & n \\
\hline $08 / 31 / 03$ & 0.28 & 184 & - & - & 0.62 & 74 \\
$10 / 21 / 03$ & - & - & 0.21 & 255 & 1.14 & 43 \\
$11 / 14 / 03$ & 0.20 & 161 & 0.23 & 83 & 0.02 & 85 \\
$03 / 13 / 04$ & 0.28 & 475 & 0.20 & 292 & 0.54 & 50 \\
$06 / 01 / 04$ & 0.40 & 230 & 0.35 & 203 & 0.22 & 193 \\
$08 / 28 / 04$ & - & - & 0.62 & 152 & 0.19 & 336 \\
$11 / 12 / 04$ & 0.25 & 185 & 0.18 & 340 & 0.35 & 192 \\
$01 / 21 / 05$ & 0.23 & 365 & 0.22 & 256 & 0.29 & 342 \\
$04 / 21 / 05$ & 0.18 & 223 & 0.45 & 175 & 0.19 & 339 \\
$07 / 18 / 05$ & 0.13 & 123 & 0.24 & 304 & 0.25 & 233 \\
$10 / 03 / 05$ & 0.24 & 190 & 0.45 & 113 & - & - \\
\hline
\end{tabular}

Dashed line indicates no samples; $\mathrm{M}: \mathrm{SL}=$ Mass to Stem Length Ratio; $\mathrm{n}=$ sample size.

Table 4. Descriptive statistics for mass to stem length (M:SL) ratios, and leaf area index (LAI), in each treatment (clearcut, partial cut, and full forest) within the Mica Creek Experimental Watershed, northern Idaho, USA.

\begin{tabular}{ccccc}
\hline \multicolumn{5}{c}{ Mass to Stem Length Ratio } \\
\hline Treatment & Min & Mean & Max & SD \\
\hline Clearcut & 0.13 & 0.24 & 0.40 & \pm 0.07 \\
Partial Cut & 0.18 & 0.31 & 0.62 & \pm 0.15 \\
Full Forest & 0.02 & 0.38 & 1.14 & \pm 0.32 \\
\hline Leaf Area Index & & \\
\hline Treatment & Min & Mean & Max & SD \\
\hline Clearcut & 0.00 & 0.00 & 0.00 & 0.00 \\
Partial Cut & 0.01 & 2.79 & 6.57 & \pm 2.29 \\
Full Forest & 4.24 & 8.24 & 11.54 & \pm 2.41 \\
\hline
\end{tabular}

$\mathrm{SD}=$ Standard Deviation

of determination $\left(\mathrm{R}^{2}\right)$ of 0.97 . Given lack of study site replication more rigorous statistical analyses were not practical. Regardless, these relationships are compelling. Future replicated studies should be conducted to supply statistical rigor and validation to the method established in the current work.

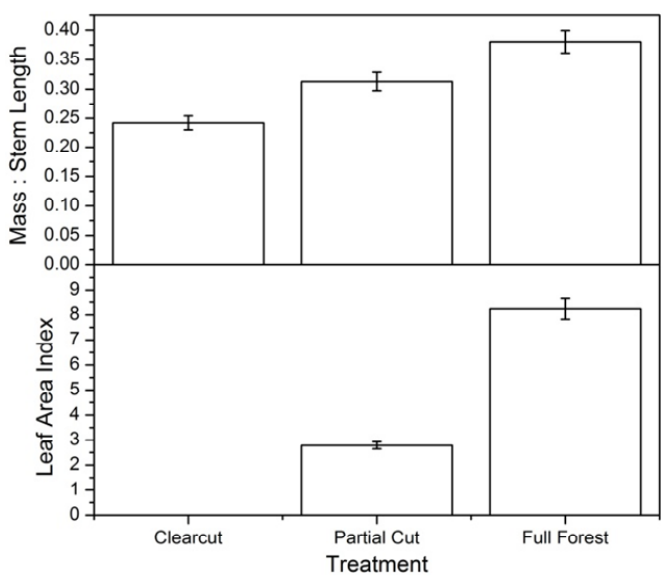

Figure 5. Mean mass to stem length (M:SL) ratios and leaf area index (LAI) in each treatment (clearcut, partial cut, and full forest) within the Mica Creek Experimental Watershed, northern Idaho, USA.

\subsection{Timber Harvest, Microclimate and Bryophyte Morphology}

Results indicated that altered environmental variables including leaf area index and air temperature subsequent to altered canopy conditions (i.e. clearcut and partial cut) corresponded to a decrease in biomass per unit stem length in $B$. frigidum. Additional replicated work should be conducted in other physiographic regions to test the method used in the current work and assess ecosystem response to perturbation. Mass to stem length ratios decreased from full forest, to partial cut, to clearcut (in that order), from 0.38 , to 0.31 , to 0.24 , respectively (Table 4 , Figure 5). This result is supported by the negative relationship between timber harvest and bryophyte physiological/morphological growth response reported by Dynesius et al. [16]. Stem elongation in bryophytes may be a response to elevated light, temperature, and nutrient levels observed in the partial cut and clearcut treatments but it is not necessarily an indication of healthier, more productive plants [56,57]. Longer stems often lacked secondary stem and leaf growth, giving them an etiolated appearance with less biomass per unit stem length (Figure 6). This observation is consistent with previous work by Furness and Grime [56,57] who showed that bryophytes growing at above optimum temperatures exhibited elongated stem growth and a reduction in overlapping leaves. They suggested that bryophytes may be capable of exploiting short-term seasonal increases in temperature and light conditions. However, prolonged exposure to those conditions leads to changes in growth form that may be detrimental to bryophyte health, including reduced leaf density and stem etiolation. Further investigations on the physiology of $B$. frigidum are warranted to better explain relationships between moss growth form and environmental conditions. 


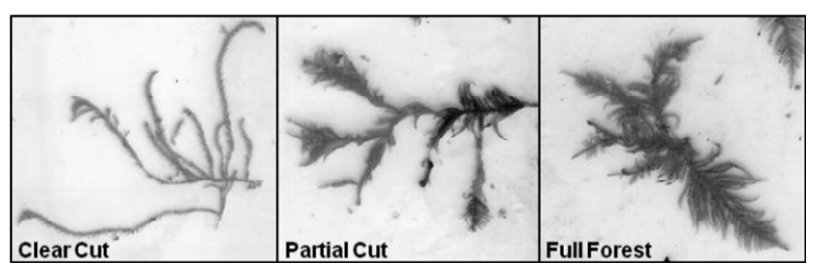

Figure 6. Representative moss (Brachythecium frigidum) samples from the clearcut, partial cut, and full forest treatments within the Mica Creek Experimental Watershed, northern Idaho, USA.

Meteorological data collected at the climate stations located mid-slope in both treatment catchments clearly illustrated microclimatic alterations subsequent to harvest (Table 2, Figure 3). There were slight differences $\left(<1^{\circ} \mathrm{C}\right)$ in average air temperature between the clearcut, partial cut, and full forest throughout the study period, with the clearcut exhibiting the widest range of air temperatures $\left(-7.21^{\circ} \mathrm{C}\right.$ to $\left.21.30^{\circ} \mathrm{C}\right)$ of all three treatments. Climate differences between treatments demonstrate how timber harvest leads to multiple environmental changes, many of which may alter bryophyte health, and thus stream ecosystem health.

Although riparian zones were protected by a 75 foot $(22.9 \mathrm{~m})$ buffer, harvesting was still permitted providing $75 \%$ of the original shade was retained. Regardless, in the steep sloped v-notch valleys of the MCEW, increased light in the adjacent harvest areas was also transmitted horizontally through the thinned riparian canopy to the stream channel, adding to the amount of light reaching stream bryophytes. Future research is warranted to better understand light attenuation through riparian stands and the impact of thinning on the stream light regime and primary production. Conceivably, any alteration to light may alter primary productivity and consequently the aquatic food web. The stream channel canopy gap should therefore be considered since, in harvested treatments, more radiation reaches the stream via horizontal transmittance following riparian thinning practices $[58,59]$. However, since bryophyte morphology is determined by multiple micrometeorological and nutrient criteria, further studies are needed to isolate the physiological response of this species to altered light regimes.

Bryophytes may exhibit a variable response to changing light intensities between partial cut and clearcut harvest treatments due to influences from other interacting variables (e.g. nutrient alterations, suspended sediment). Other published studies conducted in the MCEW confirm the effects of timber harvest on various environmental variables. For example, Hubbart et al. [14] reported significant $(\mathrm{p}<0.01)$ increases in annual water yield from harvested plots. Koeniger et al. [60] discovered alterations in the isotopic composition of snow corresponding to harvest practices. Gravelle et al. [17] found significant $(\mathrm{p}<0.001)$ increases of nitrate + nitrite $\left(\mathrm{NO}_{3}+\mathrm{NO}_{2}\right)$ concentrations in water draining from the MCEW. Ultimately, the combined effects of altered environmental variables may not be merely cumulative, but rather have a non-linear effect on bryophyte morphology. Elevated light levels and stream nutrient concentrations in the partial cut (relative to the full forest) may have a smaller combined effect on bryophyte morphology than in the clearcut, where these variables may exhibit a greater deviation from the full forest. For example, the broadcast burning that took place in the clearcut following harvest may have contributed to the higher stream nitrate concentrations, and therefore, lower M:SL ratios in that treatment. Elucidating these interactions was beyond the scope of the current work but supplies impetus for future research.

Semi-aquatic bryophytes such as B. frigidum are understood to draw the majority of their nutrients from stream water [1], so it is possible that differences in nutrient availability subsequent to harvest treatments may affect bryophyte productivity. Future controlled experiments should seek to measure the response of semiaquatic bryophytes to increased stream nitrate levels. One method of evaluating this response would be to culture bryophytes in a laboratory and measure the response. This work could easily be done in conjunction with varying light levels in order to measure both the individual and cumulative effects of these variables on bryophyte productivity.

Similar to Dynesius et al. [16], this study sought to determine the physiological/morphological growth response of bryophytes to climate alterations subsequent to timber harvest. However, in contrast to Dynesius et al. [16], this research was conducted on individuals sampled from their natural habitat, as opposed to experimental transplants. This study developed a practical method of assessing the relative response of bryophyte individuals, a method which can be utilized by land managers to evaluate the effect of harvest practices on aquatic/terrestrial ecosystem viability. While results of this work were not statistically significant, even minor responses subsequent to timber harvest, although statistically undetectable, should not be interpreted as ecologically benign. Results indicate that bryophytes respond proportionally to disturbance levels (in this case, harvest intensity). For example, this work showed that shoot lengthening was greater in the clearcut than in the partial cut, relative to the full forest. This suggests that perhaps riparian forests should be selectively harvested in order to maintain a stand density that will continue to protect riparian stream ecosystems and biological and water quality integrity in post-harvest environments. Future work is thus warranted to quantify these relationships and validate contemporary riparian forest buffer best management practices. 


\section{CONCLUSIONS}

This work adds to the limited body of knowledge pertaining to the eco-physiological response of riparian bryophytes to anthropogenic disturbance, and presents an assessment method to measure that response. Average mass to stem length ratios (M:SL) were $18.4 \%$ less in a partial cut and $36.8 \%$ less in a clearcut relative to a fully forested control, indicating stem elongation and reduced leaf density per unit stem length in the harvested treatments. Canopy density in the full forest (mean LAI $=$ 8.24) corresponded to the highest M:SL ratios (0.38) of all three treatments. Reduced canopy cover in the partial cut and clearcut (mean LAI $=2.79$ and 0.0 , respectively) corresponded to lower M:SL ratios $(0.31$ and 0.24 , respectively). Regression analysis between mean average M:SL and LAI demonstrated a high coefficient of determination $\left(\mathrm{R}^{2}\right)$ of 0.97 . Lower average air temperature in the full forest corresponded to the highest biomass per unit stem length (M:SL $=0.38$ ), whereas higher air temperatures in the clearcut and partial cut corresponded to lower biomass per unit stem length (M:SL $=0.24$ and 0.31 , respectively). These results suggest a negative relationship between altered climate conditions subsequent to timber harvest and bryophyte growth response. Average air temperatures in the riparian zones were cooler than air temperatures measured at the mid-slope climate stations, which may be explained by persistent cold air drainage that is known to occur within the watershed. Lower air temperatures in the riparian zones also indicate that riparian zones may have a cooling effect on air temperatures relative to the adjacent harvest treatments.

Bryophytes are particularly sensitive to land use impacts, as they exhibit a narrow range of tolerance to environmental disturbance. As primary producers, they are quick to respond to alterations to the riparian environment. The practical assessment method presented here can be utilized by land managers to evaluate the effect of land use practices on aquatic/terrestrial ecosystem fitness. This holds important implications for minimizing disturbance to higher trophic level organisms such as macroinvertebrates. Results of this work should serve as a springboard to further investigations (both laboratory and field) that isolate the direct bryophyte morphological response to individual environmental variables, including light and nutrient availability, and stream and air temperature. Further research is warranted to measure bryophyte response to timber harvest and other land uses (e.g. urbanization) over greater spatial and temporal scales, and to investigate the rate of bryophyte recovery from disturbance.

\section{ACKNOWLEDGEMENTS}

This research was carried out with funding provided by the United
States Department of Agriculture, and USFS Research Joint Venture Agreement \#03JV-11222065-068, USDA-CSREES 2003-01264. A profound acknowledgment is due to Malia Volke for lab, analysis, and manuscript preparation assistance. Special acknowledgments are extended to Timothy Link, John Marshall, and John Gravelle, and multiple reviewers whose feedback greatly improved the article.

\section{REFERENCES}

[1] Stream Bryophyte Group (1999) Roles of bryophytes in stream ecosystems. Journal of the North American Benthological Society, 18, 151-184. doi:10.2307/1468459

[2] Fenton, N.J., Frego, K.A. and Sims, M.R. (2003) Changes in forest floor bryophyte (moss and liverwort) communities 4 years after forest harvest. Canadian Journal of Botany, 81, 714-731. doi:10.1139/b03-063

[3] Nelson, C.R. and Halpern, C.B. (2005) Short-term effects of timber harvest and forest edges on ground-layer mosses and liverworts. Canadian Journal of Botany, 83, 610-620. doi:10.1139/b05-036

[4] Perhans, K., Appelgren, L., Jonsson, F., Nordin, U., Soderstrom, B. and Gustafsson, L. (2009) Retention patches as potential refugia for bryophytes and lichens in managed forest landscapes. Biological Conservation, 142, 11251133. doi:10.1016/j.biocon.2008.12.033

[5] Hardman, A. and McCune, B. (2010) Bryoid layer response to soil disturbance by fuel reduction treatments in a dry conifer forest. The Bryologist, 113, 235-245. doi:10.1639/0007-2745-113.2.235

[6] Root, H.T. and McCune, B. (2010) Forest floor lichen and bryophyte communities in thinned Pseudotsuga menziesiiTsuga heterophylla forests. The Bryologist, 113, 619-630. doi:10.1639/0007-2745-113.3.619

[7] Cenci, R.M. (2000) The use of aquatic moss (Fontinalis antipyretica) as monitor of contamination in standing and running waters: Limits and advantages. Journal of Limnology, 60, 53-61.

[8] Gignac, D. (2001) Bryophytes as indicators of climate change. The Bryologist, 104, 410-420. doi:10.1639/0007-2745(2001)104[0410:BAIOCC]2.0.CO ;2

[9] Turetsky, M.R. (2003) The role of bryophytes in carbon and nitrogen cycling. The Bryologist, 106, 395-409. doi:10.1639/05

[10] Binkley, D. and Graham, R.L. (1981) Biomass, production, and nutrient cycling of mosses in an old-growth Douglas-fir forest. Ecology, 62, 1387-1389. doi:10.2307/1937301

[11] Tiedemann, A.R., Quigley, T.M. and Anderson, T.D. (1988) Effects of timber harvest on stream chemistry and dissolved nutrient losses in northeast Oregon. Forest Science, 34, 344-358.

[12] Hutchens Jr., J.J., Batzer, D.P. and Reese, E. (2004) Bioassessment of silvicultural impacts in streams and wetlands of the eastern United States. Water, Air, and Soil Pollution: Focus, 4, 37-53. doi:10.1023/B:WAFO.0000012827.95431.b8 
[13] Gravelle, J.A. and Link, T.E. (2007) Influence of timber harvesting on headwater peak stream temperatures in a northern Idaho watershed. Forest Science, 53, 189-205.

[14] Hubbart, J.A., Link, T.E., Gravelle, J.A. and Elliot, W.J. (2007) Timber harvest impacts on hydrologic yield in the continental/maritime hydroclimatic region of the US. Special Issue on Headwater Forest Streams, Forest Science, 53, 169-180.

[15] Karwan, D.L., Gravelle, J.A. and Hubbart, J.A. (2007) Effects of timber harvest on suspended sediment loads in Mica Creek, Idaho. Forest Science, 53, 181-188.

[16] Dynesius, M., Åström, M. and Nilsson, C. (2008) Microclimatic buffering by logging residues and forest edges reduces clear-cutting impacts on forest bryophytes. Applied Vegetation Science, 11, 345-354. doi:10.3170/2008-7-18457

[17] Gravelle, J. A., Ice, G., Link, T. E. and Cook, D.L. (2009) Nutrient concentration dynamics in an inland Pacific Northwest watershed before and after timber harvest. Forest Ecology and Management, 257, 1663-1675. doi:10.1016/j.foreco.2009.01.017

[18] Caners, R.T., MacDonald, S.E. and Belland, R.J. (2010) Responses of boreal epiphytic bryophytes to different levels of partial canopy harvest. Botany, 88, 315-328. doi:10.1139/B09-089

[19] Dovciak, M., Halpern, C.B., Evans, S.A. and Heithecker, T.D. (2010) Forest management changes microclimate and bryophyte communities in the Cascade Mountains of western Washington. The 95th ESA Annual Meeting, Pittsburgh, 1-6 August 2010.

[20] Stehn, S.E., Webster, C.R., Glime, J.M. and Jenkins, M.A. (2010) Elevational gradients of bryophyte diversity, life forms, and community assemblage in the southern Appalachian Mountains. Canadian Journal of Forest Research, 40, 2164-2174. doi:10.1139/X10-156

[21] Baldwin, L.K., Petersen, C.L., Bradfield, G.E., Jones, W.M., Black, S.T. and Karakatsoulis, J. (2012) Bryophyte response to forest canopy treatments within the riparian zone of high-elevation small streams. Canadian Journal of Forest Research, 42, 141-156. doi:10.1139/x11-165

[22] Sollows, M.C., Frego, K.A. and Norfolk, C. (2001) Recovery of Bazzania trilobata following dessication. The Bryologist, 104, 421-429. doi:10.1639/0007-2745(2001)104[0421:ROBTFD]2.0.C $\underline{\mathrm{O} ; 2}$

[23] Dynesius, M. and Hylander, K. (2007) Resilience to bryophyte communities to clear-cutting of boreal stream-side forests. Biological Conservation, 135, 423-434. doi:10.1016/j.biocon.2006.10.010

[24] Wozniewski, R. and Diekmann, M. (2009) Bryophyte vegetation on decaying spruce logs in wind throws. Forstarchiv, 80, 173-180.

[25] Arseneault, J., Fenton, N.J. and Bergeron, Y. (2012) Effects of variable canopy retention harvest on epixylic bryophytes in boreal black spruce-Feathermoss forests. Canadian Journal of Forest Research, 42, 1467-1476. doi:10.1139/x2012-054

[26] Shields, J.M., Webster, C.R. and Glime, J.M. (2007)
Bryophyte community response to silvicultural opening size in a managed northern hardwood forest. Forest Ecology and Management, 252, 222-229. doi:10.1016/j.foreco.2007.06.048

[27] McGee, G.G. and Kimmerer, R.W. (2002) Forest age and management effects on epiphytic bryophyte communities in Adirondack northern hardwood forests, New York, USA. Canadian Journal of Forest Research, 32, 15621576. doi:10.1139/x02-083

[28] Cleavitt, N.L., Eschtruth, A.K., Battles, J.J. and Fahey, T.J. (2008) Bryophyte response to eastern hemlock decline caused by hemlock woolly adelgid infestation. Journal of the Torrey Botanical Society, 135, 12-25. doi:10.3159/07-RA-030.1

[29] Mathieson, K. and Frego, K. (2008) Bryophyte-substrate associations and relationships to forest management responses in the Acadian Forest of southern New Brunswick. Eastern CANUSA Forest Science Conference Proceedings, Orono, 17-18 October 2008.

[30] Witkowski, A. D. and Frego, K.A. (2008) The response of bryophytes to pre-commercial thinning in the Acadian Forest. Eastern CANUSA Forest Science Conference Proceedings, Orono, 17-18 October 2008.

[31] Dynesius, M., Hylander, K. and Nilsson, C. (2009) High resilience of bryophyte assemblages in streamside compared to upland forests. Ecology, 90, 1042-1054. doi:10.1890/07-1822.1

[32] Hudson, J.M.G. and Henry, G.H.R. (2009) Increased plant biomass in a High Arctic heath community from 1981 to 2008. Ecology, 90, 2657-2663. doi:10.1890/09-0102.1

[33] Lang, S.I., Cornelissen, J.H.C., Shaver, G.R., Ahrens, M., Callaghan, T.V., Molau, U., Ter Braak, C.J.F., Holzer, A. and Aerts, R. (2012) Arctic warming on two continents has consistent negative effects on lichen diversity and mixed effects on bryophyte diversity. Global Change Biology, 18, 1096-1107. doi:10.1111/j.1365-2486.2011.02570.x

[34] Hudson, J.M.G. and Henry, G.H.R. (2010) High Arctic plant community resists 15 years of experimental warming. Journal of Ecology, 98, 1035-1041. doi:10.1111/j.1365-2745.2010.01690.x

[35] Arroniz-Crespo, M., Gwynn-Jones, D., Callaghan, T.V., Nunez-Olivera, E., Martınez-Abaigar, J., Horton, P. and Phoenix, G.K. (2011) Impacts of long-term enhanced UV$\mathrm{B}$ radiation on bryophytes in two sub-Arctic heathland sites of contrasting water availability. Annals of Botany, 108, 557-565. doi:10.1093/aob/mcr178

[36] Bjerke, J.W., Bokhorst, S., Zielke, M., Callaghan, T.V., Bowles, F.W. and Phoenix, G.K. (2011) Contrasting sensitivity to extreme winter warming events of dominant sub-Arctic heathland bryophyte and lichen species. Journal of Ecology, 99, 1481-1488. doi:10.1111/j.1365-2745.2011.01859.x

[37] Arróniz-Crespo, M., Leake, J.R., Horton, P. and Phoenix, G.K. (2008) Bryophyte physiological responses to, and recovery from, long-term nitrogen deposition and phosphorus fertilisation in acidic grassland. New Phytologist, 180, 864-874. doi:10.1111/j.1469-8137.2008.02617.x 
[38] Bu, Z.J., Rydin, H. and Chen, X. (2011) Direct and interaction-mediated effects of environmental changes on peatland bryophytes. Oecologia, 166, 555-563. doi:10.1007/s00442-010-1880-1

[39] Hubbart, J.A., Link, T. and Elliot, W.J. (2011) Implementation strategies to improve WEPP snowmelt simulations in mountainous terrain. American Society of Agricultural and Biological Engineers, 54, 1333-1345.

[40] Idaho Department of Lands (IDL) (2000) Forest practices cumulative watershed effects process for Idaho. Idaho Department of Lands, Boise.

[41] White, J.D., Running, S.W., Nemani, R., Keane, R.E. and Ryan, K.C. (1997) Measurement and remote sensing of LAI in Rocky Mountain montane ecosystems. Canadian Journal of Forest Research, 27, 1714-1727. doi:10.1139/x97-142

[42] Keane, R.E., Reinhardt, E.D., Scott, J., Gray, K. and Reardon, J. (2005) Estimating forest canopy bulk density using six indirect methods. Canadian Journal of Forest Research, 35, 724-739. doi:10.1139/x04-213

[43] Marshall, J.D. and Waring, R.H. (1986) Comparison of methods of estimating leaf-area index in old-growth Douglas-fir. Ecology, 64, 975-979. doi:10.2307/1939820

[44] Duursma, R.A., Marshall, J.D. and Robinson, A.P. (2003) Leaf area index inferred from solar beam transmission in mixed conifer forests on complex terrain. Agricultural and Forest Meteorology, 118, 221-236. doi:10.1016/S0168-1923(03)00109-6

[45] Hubbart, J.A., Link, T.E., Campbell, C. and Cobos, D. (2005) An evaluation of a low-cost air temperature measurement system. Hydrological Processes, 19, 1517-1523. doi:10.1002/hyp.5861

[46] Hubbart, J.A. (2011) An inexpensive alternative solar radiation shield for ambient air temperature micro-sensors. Journal of Natural and Environmental Sciences, 2, 9-14.

[47] Jonsson, B.G. (1996) Riparian bryophytes of the H.J. Andrews experimental forest in the western Cascades, Oregon. The Bryologist, 99, 226-235. doi: $10.2307 / 3244554$

[48] Conrad, H.S. and Redfearn, P.L. (1979) How to know the mosses and liverworts. Wm. C. Brown Company Publishers, New York.

[49] Dhindsa, R.S. and Matowe, W. (1981) Drought tolerance in 2 mosses correlated with enzymatic defense against lipid per oxidation. Journal of Experimental Botany, 32, 79-92. doi:10.1093/jxb/32.1.79

[50] Martinez-Abaigar, J., Nunez-Olivera, E. and Beaucourt, N. (2002) Moss communities in the irrigation channels of the river Iregua basin (La Rioja, northern Spain). Cryptogamie Bryologie, 23, 97-117.

[51] Jönsson, K.I. (2003) Population density and species composition of moss-loving tardigrades in a boreo-nemoral forest. Ecography, 26, 356-364. doi:10.1034/j.1600-0587.2003.03458.x

[52] Vargha, B., Ötvös, E. and Tuba, Z. (2002) Investigations on ecological effects of heavy metal pollution in Hungary by moss-dwelling water bears (Tardigrada), as bioindicators. Annals of Agriculture and Environmental Medicine, 9, 141-146.

[53] Sokal, R.R. and Rohlf, F.J. (1981) Biometry: The princeples and practice of statistics in biological research. Freeman, New York.

[54] Zar J.H. (1999) Biostatistical analysis. Prentice Hall, Upper Saddle River.

[55] Hubbart, J.A., Kavanagh, K.L., Pangle, R., Link, T.E. and Schotzko, A. (2007) Cold air drainage and modeled nocturnal leaf water potential in complex forested terrain. Tree Physiology, 27, 631-639. doi:10.1093/treephys/27.4.631

[56] Furness, S.B. and Grime, J.P. (1982) Growth rate and temperature responses in bryophytes: I. An investigation of Brachythecium Rutabulum. The Journal of Ecology, 70, 513-523. doi: $10.2307 / 2259919$

[57] Furness, S.B. and Grime, J.P. (1982) Growth rate and temperature responses in bryophytes: II. A comparative study of species of contrasted ecology. The Journal of Ecology, 70, 525-536. doi:10.2307/2259920

[58] Bonan, G. (2002) Ecological climatology: Concepts and applications. Cambridge University Press, Cambridge.

[59] Monteith, J.L. (1973) Principles of environmental physics. Edward Arnold Limited, London.

[60] Koeniger, P., Hubbart, J.A., Link, T. and Marshall, J.D. (2008) Isotopic variation of snow cover and streamflow in response to changes in canopy structure in a snowdominated mountain catchment. Hydrological Processes, $1-10$. 